\title{
Isolation of the pathogen Vibrio tapetis and defense parameters in brown ring diseased Manila clams Ruditapes philippinarum cultivated in England
}

\author{
Bassem Allam $^{1, *}$, Christine Paillard $^{1}$, Alan Howard ${ }^{2}$, Marcel Le Pennec ${ }^{1}$ \\ ${ }^{1}$ Institut Universitaire Européen de la Mer, UMR 6539, Université de Bretagne Occidentale, Technopôle Brest-Iroise, \\ 29280 Plouzané, France \\ ${ }^{2}$ CEFAS Weymouth Laboratory, Barrack Road, The Note, DT4 8UB Weymouth Dorset, United Kingdom
}

\begin{abstract}
The Manila clam Ruditapes philippinarum was introduced for aquacultural purposes to Europe in the 1970s. In 1987, brown ring disease (BRD), caused by Vibrio tapetis, appeared in clams cultivated in Brouënou (Finistère, France) and later became increasingly widespread and was reported in cultivated and wild clams existing on the Atlantic coasts of France and Spain. The present study reports, for the first time, the presence of BRD in clams cultivated in England. The etiologic bacterium was isolated and identified using bacteriological and serological techniques. The defence response of affected clams was also studied and significant changes in the hematological and biochemical characteristics of hemolymph and extrapallial fluids were demonstrated. Significant mobilization of hemocytes toward the extrapallial fluids, in contact with the main site of infection (mantle-periostracal lamina area), was observed, suggesting a role for these pseudo-internal compartments in the preservation of clam health.
\end{abstract}

KEY WORDS: Shell disease Bivalve - Bacteria Immune defense $\cdot$ Lysozyme $\cdot$ Hemocyte

\section{INTRODUCTION}

In Europe, the Manila clam Ruditapes philippinarum, which is of Indo-Pacific origin, was introduced for aquacultural purposes to France between 1972 and 1975. England in 1980, and later in Spain and Italy in 1985 (Breber 1985, Flassch \& Leborgne 1992). In France, this new venerid culture became increasingly widespread until 1986. Since this time, mass mortalities in clam beds have occurred, associated with Brown Ring Disease (BRD), a bacterial disease caused by a Vibrio strain first described as Vibrio P1 and named more recently Vibrio tapetis (Paillard et al. 1994, Borrego et al. 1996a). Moribund clams exhibited a brown conchiolin deposit on the inner face of the shell, within

- Present address: Laboratoire d'Ecologie Animale, Université d'Angers, 2, Boulevard Lavoisier, 49045 Angers Cedex, France. E-mail: allam@sciences.univ-angers.fr the extrapallial space. Histological observations of naturally and experimentally infected clams showed that $V$. tapetis colonize and alter the periostracal lamina (Paillard \& Maes 1995, Allam et al. 1996). The disorganized periostracal lamina accumulates, forming the brown organic deposit.

In Europe, BRD has been observed in France and Spain in cultivated and recently established wild populations of Ruditapes philippinarum (Fig. 1). In 1990 , BRD was also reported in Italy, in a lagoon of the north Adriatic Sea (Paillard et al. 1994). The typical BRD syndrome has not been reported on the Indo-Pacific coast nor the west coast of the United States and Canada, where this species is also cultivated (Paillard et al. 1994). Manila clams with an abnormal brown organic deposit, similar to the one observed in brown ring diseased animals, have been observed in 1997 in clams cultivated in southern England (Poole Harbour, Fig. 1). However, it was not known if these signs were the 


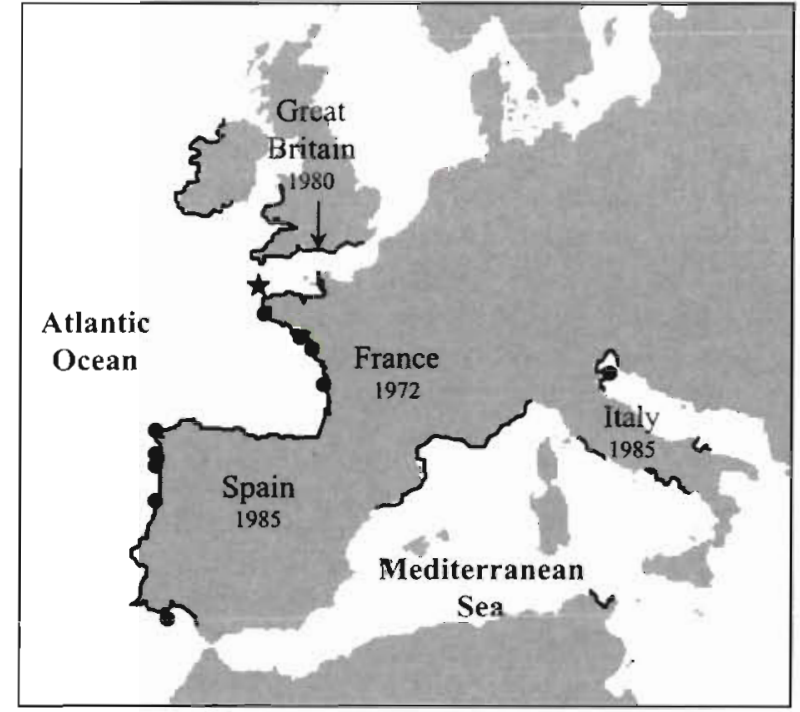

Fig. 1. Ruditapes philippinarum. Distribution of clams (black lines) and brown ring disease (BRD black dots) in Europe. Years are the date of introduction of the species in each country. $\star$ : first apparition of BRD (in 1987 at Brouënou, Finistère). Clams used in this study were sampled in Poole Harbor, southern England (arrow)

result of the infection of clams with Vibrio tapetis, since other bacteria (Dungan \& Elston 1988, Dungan et al. 1989) as well as other parasites, such as fungus and trematodes, may cause similar deposits in bivalves (see review by Paillard et al. 1994).

Since the success or failure of the pathogen in establishing infection depends partly on the effectiveness of the host defence reaction, the response of clams to experimental challenge with Vibrio tapetis has been investigated. These studies have demonstrated significant changes in the number and type of circulating hemocytes as well as antibacterial and enzymatic activities (peptidases, lytic enzymes) (Oubella et al. 1993, 1994, 1996, Allam 1998, Allam \& Auffret 2000, Allam et al. 2000). As a result of these findings, a new research strategy, which includes the study of defence factors in clam central (CEF) and peripheral (PEF) extrapallial fluids, has been developed (Allam \& Paillard 1998, Allam et al. 2000) and has demonstrated great changes of these factors (increase in hemocyte counts and lysozyme activity) following experimental challenge. These fluids, particularly the PEF, are of major interest in the case of $\mathrm{BRD}$, since this is the space where the disease symptom occurs and where the pathogen is abundant (Allam et al. 1996). However, despite the information available on the effect of experimental challenge with $V$. tapetis on defence parameters in clams, little is known about the response of diseased clams collected in the field.
This work was designed to answer 3 questions: (1) is the abnormal organic deposit observed in clams cultivated in England caused by infection with Vibrio tapetis? If so, it will be the first report of BRD in this country; (2) is there any modulation of defence factors in naturally diseased animals; and (3) what is the defence strategy used by the host to fight this infection? To investigate these problems, we attempted the isolation and identification of $V$. tapetis from clams showing the characteristic brown deposit using bacteriological and immunological methods. Once infection with BRD was confirmed, hemocyte counts and lysozyme activity measurements were performed from the hemolymph and extrapallial fluids of both healthy and diseased clams to evaluate the alterations in defence parameters in parasitized individuals.

\section{MATERIALS AND METHODS}

Bacteriology. Adult Ruditapes philippinarum were collected from clam beds at Poole Harbour (southern England, Fig. 1) in June 1997. The external shell surface of clams was washed by scrubbing under running tap water to remove mud and marine life, washed with $70 \%$ ethanol and allowed to dry. Clams were then opened aseptically by cutting the adductor muscle with a sterile knife. The mantle edge, including the periostracal lamina, of clams exhibiting the brown ring syndrome was surgically separated from the rest of the flesh and transferred to a sterile Eppendorf vial, then vortexed in sterile sea water (SSW; 1/10, w/v). A volume of $0.1 \mathrm{ml}$ of serial dilutions (in SSW) of the resulting suspension was plated on marine agar and incubated for $72 \mathrm{~h}$ at $20^{\circ} \mathrm{C}$.

The isolation of Vibrio tapetis was performed according to Maes (1992). Briefly, replicate subcultures were used for testing $4 \mathrm{~V}$. tapetis key characteristics: nonutilization of sucrose and mannitol, growth on TCBS (thiosulfate citrate bile sucrose), and failure to grow above $28^{\circ} \mathrm{C}$. The colonies meeting these 4 requirements were purified and subjected to API 20E gallery system analysis and a slide agglutination test using rabbit anti- $V$. tapetis serum for confirmation.

The total bacterial burden in the CEF of diseased clams was also measured as described in Allam \& Paillard (1998). Sub-samples of CEF were serially diluted and plated on standard marine agar or inoculated in standard marine culture broth. Counts were made after 2 wk of incubation at $20^{\circ} \mathrm{C}$. Eighteen clams were analyzed for the presence of viable bacteria in their CEF. Since there are differences in the development and the localization of the organic deposit between the left and the right valve of a single individual, CEF sampled from each valve was ana- 
lyzed separately in 9 clams. For the other 9 clams, the CEF from both valves was pooled before bacterial analysis.

Pathogenicity test. The isolated strain of Vibrio tapetis was inoculated into the pallial cavity of healthy clams as described in Paillard \& Maes (1995) with slight modifications. Briefly, $0.5 \mathrm{ml}$ of a suspension containing $10^{8}$ bacteria $\mathrm{ml}^{-1}$ in SSW was injected into each clam. A first control set was inoculated with $V$. tapetis strains isolated from French diseased clams (laboratory collection strains) and a second control set was injected with SSW. Four weeks following challenge, all clams were opened and the percentage of diseased individuals was calculated.

Immunofluorescence detection. With the use of a binocular microscope, periostracal lamina and conchiolin deposit fragments were carefully transferred to sterile glass slides. An indirect immunofluorescence method using an anti-Vibrio tapetis rabbit serum (primary antibody) was applied to these fragments to identify the pathogen as described by Allam et al. (1996). Fluorescein isothiocyanate-conjugated goat anti-rabbit antibody was used as a secondary antibody. After incubation, the preparations were generously rinsed with phosphate-buffered saline and mounted in non-fluorescent microscopic oil before examination under epifluorescence microscopy.

Defence parameters. Fluid sampling: Hemolymph (HE) samples were withdrawn from the adductor muscle. Extrapallial fluid samples were collected by drilling holes through the external face of the shell without cutting the mantle. One hole was made in the central part of each valve to obtain CEF and a second in the sinusal part for the PEF (Allam \& Paillard 1998).

Hemocyte counts: Samples were instantaneously diluted (v/v) with $0.2 \%$ ice-cold SSW-trypan blue solution and total and viable hemocyte counts were simultaneously determined with a hemacytometer. Results of total and viable hemocyte count are presented as $10^{6}$ cells $\mathrm{ml}^{-1}$ and percentage of dead cells respectively.

Lysozyme activity measurement: Samples were centrifuged at $400 \times g$ for $10 \mathrm{~min}$ at $4^{\circ} \mathrm{C}$. Supernatants were withdrawn and the pelleted hemocytes were resuspended in SSW and adjusted to $10^{6}$ cell ml-1, then sonicated (40 min in ice-cold water) to obtain cell lysate. Lysozyme concentrations in supernatants and cell lysate were determined spectrophotometrically according to Allam \& Paillard (1998) using chicken egg white lysozyme (CEW, Sigma) as standard. Supernatant protein was measured using bovine serum albumin as standard (Bradford 1976). Lysozyme activity is given in concentration of CEW lysozyme equivalent expressed in $\mu \mathrm{g} \mathrm{mg}^{-1}$ protein for the supernatants, and per $10^{6}$ cells for the cell lysate.

Classification of BRD syndrome. Disease development was determined after meats were removed from shells as described by Paillard \& Maes (1994). A disease index, taking into account the extent, location and thickness of the deposit was calculated. According to these authors, the degrees of the BRD ranged from few microscopic brown spots in early stage (BRD Index = -1) to a complete thick brown ring in advanced stage (BRD Index $=19$ ).

Statistical analysis. Differences between test and control clams in mean total and viable cell counts, protein and lysozyme levels were assessed using Student's t-test. Correlation between defence parameters and BRD Index was analyzed using Spearman's rank correlation test. Significance levels were noted for each comparison.

\section{RESULTS}

\section{BRD syndrome description}

The typical conchiolin deposit was visible to the eye on the inner surface of the shell of 51 among 61 clams examined (Table 1). Signs of the disease were not detected macroscopically or microscopically in the remaining 10 clams which were, consequently, considered as healthy. The brown deposit was generally localized between the pallial line and the edge of the shell, within the peripheral compartment. In $94 \%$ of diseased clams, a complete ring of organic materials was observed in at least 1 valve. The deposit was also frequently detected in the sinusal compartment $(63 \%)$ and to a lower extent in the central and subarticular compartments. The disease index varied between 1 and 15 on a theoretical scale of 19 maximum. Shell regeneration, which consists of

Table 1. Ruditapes philippinarum. Localization of the brown organic deposit in clams cultured in Poole Harbor

\begin{tabular}{|lcccccc|}
\hline & Total & $\begin{array}{c}\text { Complete } \\
\text { ring }\end{array}$ & $\begin{array}{c}\text { Peripheral } \\
\text { compartment }\end{array}$ & $\begin{array}{c}\text { Sinusal } \\
\text { compartment }\end{array}$ & $\begin{array}{c}\text { Central } \\
\text { compartment }\end{array}$ & Recalcification \\
\hline No. of clams & 51 & 48 & 51 & 32 & 20 & 42 \\
Percentage & 100 & 94 & 100 & 63 & 39 & 82 \\
\hline
\end{tabular}




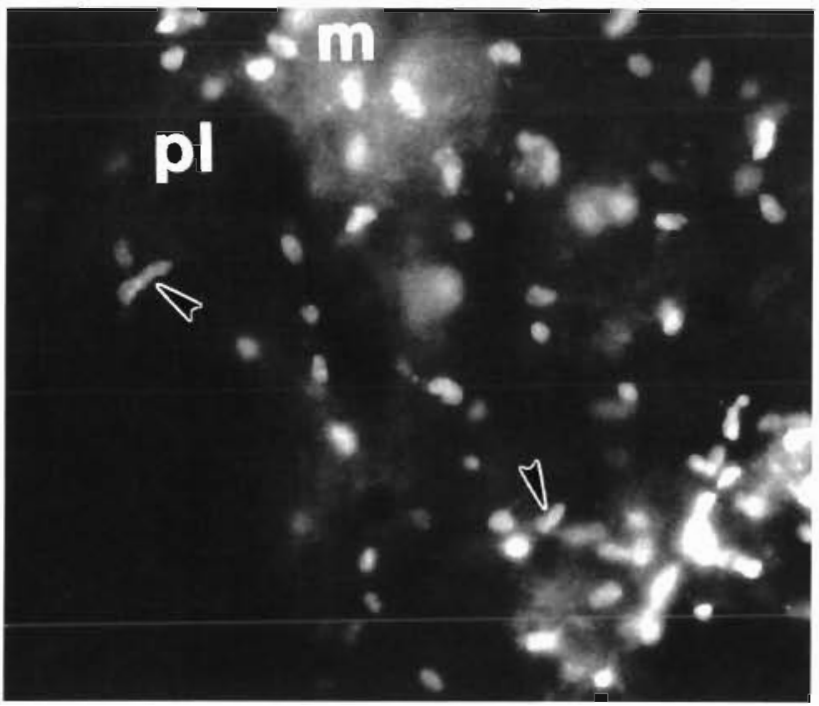

Fig. 2. Vibrio tapetis infecting Ruditapes philippinarum. Microscopic detection of the pathogen (indirect immunofluorescence technique). V. tapetis adhering to fragments of the periostracal lamina of a diseased clam. pl: periostracal lamina; m: mucus; arrowheads: bacteria $(\times 2175)$

recovering the brown deposit with new calcified layers (Paillard \& Maes 1994), was observed in $82 \%$ of diseased clams.

\section{Detection and isolation of the pathogen}

Microscopic observations

The use of the immunofluorescence detection technique on fragments of the periostracal lamina and the conchiolin deposit revealed the presence of numerous Vibrio tapetis (Fig. 2). Hemocyte-like cells were also observed on the periostracal lamina of diseased clams, near the pathogen. The pathogen was not observed on the periostracal lamina of healthy clams.

\section{Isolation and virulence of the pathogen}

The use of 4 key characteristics of the pathogen coupled with a slide agglutination test using rabbit antiVibrio tapetis serum allowed us to isolate a $V$. tapetis strain from diseased clams. The phenotypic profile (API 20E) of the isolated strain was similar to the profile of $V$. tapetis described by Paillard et al. (1994). The inoculation of this strain into healthy clams caused the development of the BRD in $75 \%$ of contaminated clams. This result was in the range of those observed following the challenge with French isolates of $V$. tapetis $(60$ to $98 \%)$.

\section{Defence parameters}

Differences between healthy and brown ring diseased clams

Total hemocyte counts (THC) were significantly higher in the HE, CEF and PEF of diseased clams when compared to healthy clams (Table 2). There was no significant difference in THC among $\mathrm{HE}, \mathrm{CEF}$ and PEF of healthy clams. In diseased individuals, THC was extremely high in PEF $\left(6.96 \times 10^{6} \mathrm{cells}^{-1}\right)$ followed

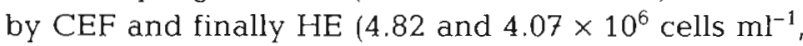
respectively).

In all compartments, the percentage of dead cells was significantly higher in diseased than in healthy clams (Table 2). The highest percentage of dead cells was found in the PEF (about $14 \%$ ).

The supernatant of $\mathrm{HE}$ and $\mathrm{CEF}$ of diseased clams contained low protein concentrations when compared with healthy individuals. In PEF supernatant, no significant differences in protein were found between healthy and diseased clams.

Lysozyme activity in the supernatant of CEF and PEF was 2 to 3 times higher in diseased than in healthy individuals (Table 2). For HE, the situation was the opposite, with highest lysozyme activity in supernatant of healthy clams. No significant differences were observed in mean lysozyme activity in cell lysates between healthy and diseased clams (Table 2).

\section{Relation with disease stages}

Significant positive correlations were found between the BRD Index and THC in CEF and PEF but not in HE (Table 3). In all compartments, positive correlations were found between the BRD Index and the percentage of dead cells.

For protein and lysozyme correlation analysis, only $\mathrm{HE}$ and CEF were studied because PEF samples were pooled before protein and enzyme determination. In HE and CEF supernatant, severely infected clams (high BRD Index) showed the lowest protein contents (Table 3). For supernatant lysozyme, a negative correlation was observed in the $\mathrm{HE}$. High negative correlations were found between BRD Index and cell lysate lysozyme in $\mathrm{HE}(\mathrm{r}=-0.90, \mathrm{p}=0.003)$ and $\mathrm{CEF}$ $(\mathrm{r}=-0.86, \mathrm{p}=0.004)$.

\section{Total bacterial burden in the CEF}

A bacteriologically sterile CEF was encountered in some clams showing heavy conchiolin deposits 
Table 2. Ruditapes philippinarum. Cellular and humoral parameters in the body fluids of healthy and diseased clams (mean \pm standard error). Significant differences (Student's $t$-test) between healthy and diseased clams were noted at the 0.05 level (thin double bars) or the 0.01 level (bold double bars). Number of clams is indicated within parentheses. THC: total hemocyte counts. SN: supernatant, CL: cell lysate

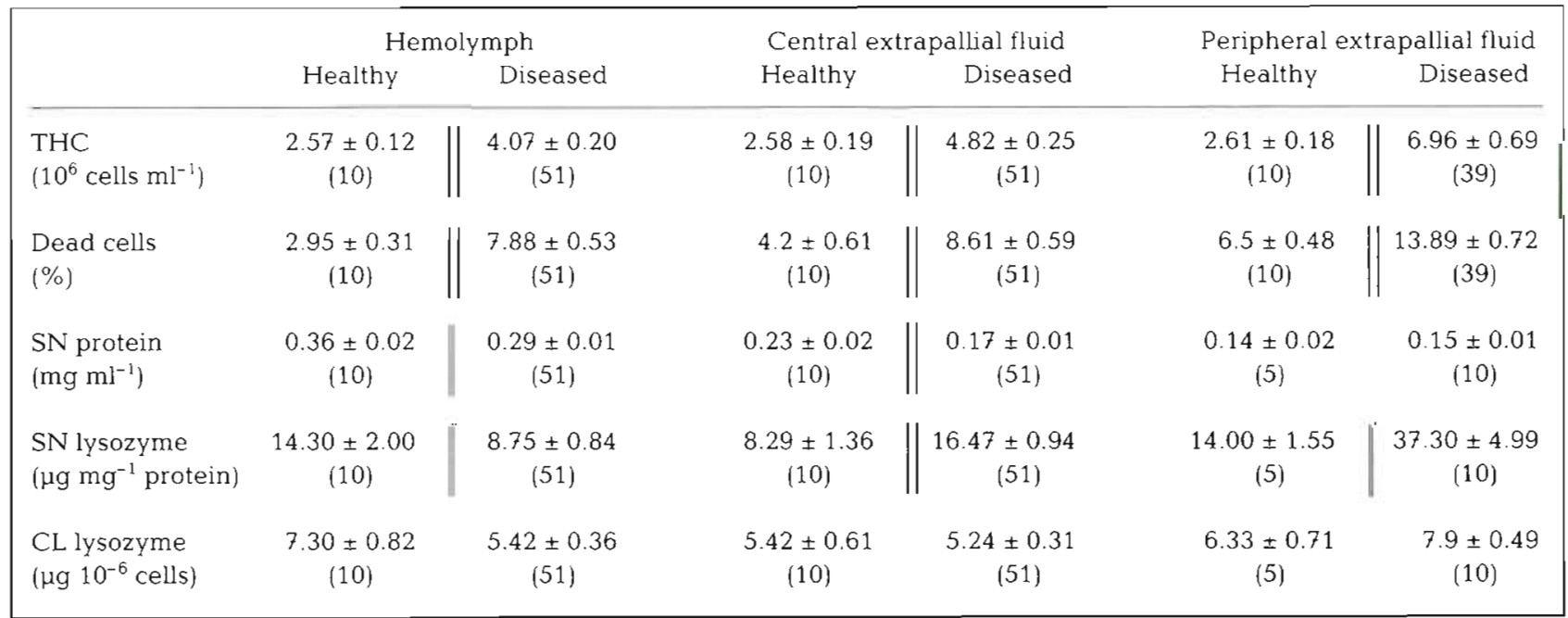

(Table 4, clam nos. $1,2,3,6,9,10,12,14$, and 17), whereas cultivable bacteria were observed in others (clam nos. 4, 5, 7, 8, 11, 13, 15, 16, and 18). In some individuals, viable bacteria were detected in only 1 of the 2 sampled valves (clam nos. 7 and 8). In clam no. 8, bacteria were detected only in the CEF sampled from the valve that contained the organic deposit within the central compartment. On the other hand, cultivable bacteria were detected in the CEF of some diseased clams without the presence of the abnormal organic deposit within the central compartment of the shell (clam nos. 7 and 15). Vibrio tapetis were detected, using immunofluorescence techniques, in all culture broths that displayed a bacterial growth.

\section{DISCUSSION}

The present study clearly demonstrates the occurrence of BRD in Manila clam cultivated in England. The etiologic agent was identified and isolated using improved bacteriological and immunological methods previously described (Maes 1992, Paillard \& Maes 1995, Allam et al. 1996). The studies also showed that the Vibrio tapetis strains from diseased clams in the present study from England have a phenotypic profile similar to those from France (Paillard et al. 1994). In addition, the isolates demonstrated their ability to induce the disease at comparable levels when inoculated into healthy clams. Microscopic observations of diseased individuals using an immunofluorescence tech-

Table 3. Ruditapes philippinarum. Correlation between BRD Index and (a) cellular and (b) biochemical parameters in the hemolymph (HE), the central (CEF) and the peripheral (PEF) extrapallial fluids. The arithmetic mean of each parameter was calculated from clams having the same BRD Index before the application of Spearman's rank correlation test. The number of rank class ( $N$ ) was equal to 12 unless for the PEF ( $N=11)$. r: correlation coefficient, $p$ : probability

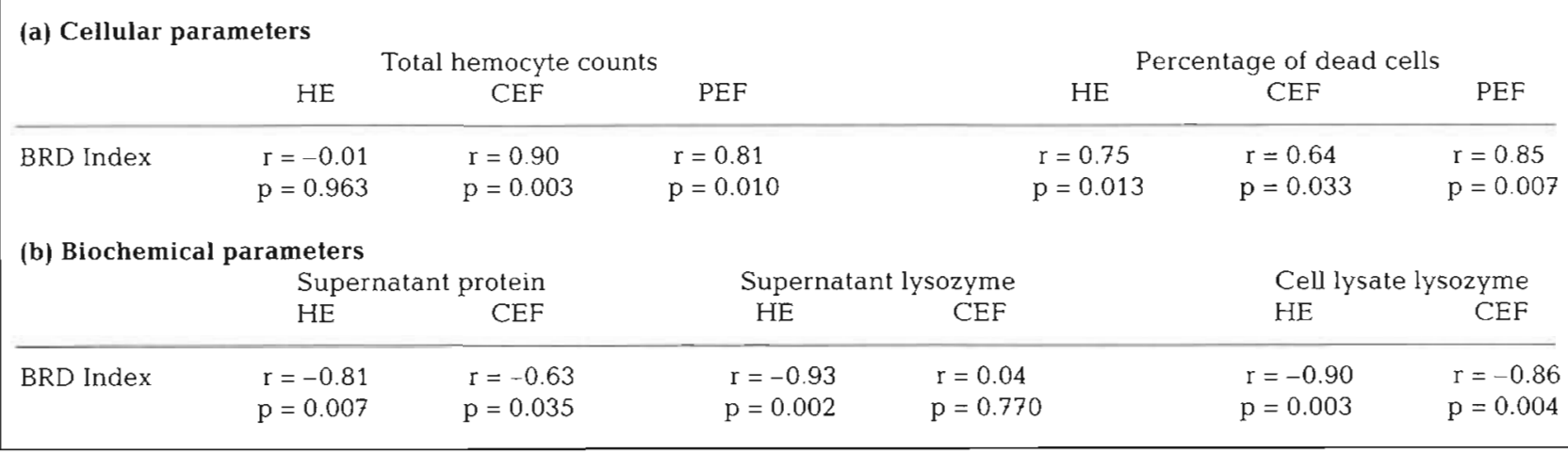


Table 4. Vibrio tapetis infecting Ruditapes philippinarum. Total bacterial burden in the central extrapallial fluid of diseased clams with different BRD Index. Central: presence ( $L$ : in the left valve, $R$ : in the right valve) and absence $(0)$ of the abnormal organic deposit in the central compartment of the shell

\begin{tabular}{|c|c|c|c|c|}
\hline \multirow[t]{2}{*}{$\begin{array}{l}\text { Clam } \\
\text { no. }\end{array}$} & \multirow[t]{2}{*}{$\begin{array}{l}\mathrm{BRD} \\
\text { Index }\end{array}$} & \multirow[t]{2}{*}{ Central } & \multicolumn{2}{|c|}{$\begin{array}{l}\text { Bacterial burden } \\
\left(\log _{10} \mathrm{cfu} \mathrm{ml}^{-1}\right)\end{array}$} \\
\hline & & & $\mathrm{L}$ & $\mathrm{R}$ \\
\hline 1 & 11 & 0 & 0 & 0 \\
\hline 2 & 10 & $\mathrm{R}$ & 0 & 0 \\
\hline 3 & 7 & 0 & 0 & 0 \\
\hline 4 & 15 & $\mathrm{~L}, \mathrm{R}$ & 5.9 & 4.5 \\
\hline 5 & 15 & $L, R$ & 2.7 & 3.2 \\
\hline 6 & 2 & 0 & 0 & 0 \\
\hline 7 & 7 & 0 & 5.3 & 0 \\
\hline 8 & 13 & $\mathrm{~L}$ & 3.7 & 0 \\
\hline \multirow[t]{2}{*}{9} & 5 & 0 & 0 & 0 \\
\hline & & & \multicolumn{2}{|c|}{$\begin{array}{c}\text { Pooled samples from } \\
\text { both valves }\end{array}$} \\
\hline 10 & 6 & 0 & \multicolumn{2}{|c|}{0} \\
\hline 11 & 10 & $\mathrm{~L}, \mathrm{R}$ & \multicolumn{2}{|c|}{3.3} \\
\hline 12 & 11 & $\mathrm{R}$ & \multicolumn{2}{|c|}{0} \\
\hline 13 & 11 & $L, R$ & \multicolumn{2}{|c|}{4.1} \\
\hline 14 & 6 & 0 & \multicolumn{2}{|c|}{0} \\
\hline 15 & 9 & 0 & \multicolumn{2}{|c|}{3.8} \\
\hline 16 & 15 & $\mathrm{~L}, \mathrm{R}$ & \multicolumn{2}{|c|}{3.6} \\
\hline 17 & 9 & 0 & \multicolumn{2}{|c|}{0} \\
\hline 18 & 15 & $\mathrm{~L}, \mathrm{R}$ & \multicolumn{2}{|c|}{2.4} \\
\hline
\end{tabular}

nique revealed that the periostracal lamina and the organic deposit were heavily colonized by $V$. tapetis in accordance with previous reports in naturally and experimentally diseased clams (Paillard \& Maes 1995, Allam et al. 1996)

In Europe, Ruditapes philippinarum was first introduced to France for aquacultural purposes. This exogenous species has rapidly colonized French coasts and formed wild populations. BRD was first noted in $R$. philippinarum cultivated on the Western French coast (Brouënou, Finistère, Paillard et al. 1989) and since then appears to have spread to wild and cultivated populations in France and neighboring countries (Paillard et al. 1994). Based on experimental and field epidemiological studies, particularly those that describe slow growth of Vibrio tapetis and low development of the disease at temperatures higher than 21 to $25^{\circ} \mathrm{C}$, Paillard et al. (1994, and unpubl.) claimed that BRD is a 'cold water' disease which appears to be spreading through Manila clam populations along the Atlantic coasts of Western Europe. We therefore could suspect that BRD will continue to spread to cultivated and wild $R$. philippinarum (and, to a lesser degree, the native species Ruditapes decussatus) populations in England. Commercial exchange of juveniles and/or larvae between countries and within regions of a same country, under particular hydrological conditions, probably help the transmission and development of the disease.

Almost all previous studies on molluscan immune system were focused on the investigation of hemocytes and humoral defence factors in $\mathrm{HE}$ (see reviews by Cheng 1981, 1996, Bayne 1983, Chu 1988, Feng 1988, Roch 1999). The new research strategy that we developed in our laboratory is based on the investigation of defence parameters not only in this internal fluid but also in the extrapallial fluids which bathe the infection site and where the pathogen is most abundant (Allam et al. 1996, Allam 1998). In healthy clams, we have demonstrated the presence of consistent hemocyte and lysozyme activity in the CEF and PEF (Allam \& Paillard 1998). In the present study, significantly higher THC and lysozyme activity were observed in the body fluids of diseased clams, particularly in the extrapallial fluids (CEF and PEF), in comparison with those in healthy individuals. In molluscan HE, hemocytosis is one of the cellular defence responses (Cheng 1981, Feng 1988) and the mobilization of hemocytes from tissues toward the circulatory compartment following pathological stress has been suggested in several molluscan species (Sparks \& Morado 1988, Mounkassa \& Jourdane 1990, Ford et al. 1993, La Peyre et al. 1995).

In our study, high THC in the extrapallial fluids (CEF and PEF) of diseased clams suggest a mobilization of immunocompetent cells to this compartment. As in the HE of the oyster Crassostrea virginica infected with Perkinsus marinus (Chu \& La Peyre 1993) and Haplosporidium nelsoni (Ford et al. 1993), THC increased in the CEF and the PEF of clams in proportion to the intensity of the infection with BRD (BRD Index). Similar processes have already been observed in experimentally infected Ruditapes philippinarum with a progressive increase of THC in the CEF (PEF was not studied in this previous work) with the increase in BRD prevalence and index (Allam 1998, Allam et al. 2000). In these previous studies, the increase of THC in the CEF after experimental challenge with Vibrio tapetis was interpreted as a mobilization of hemocytes toward the site of infection, e.g. the mantle area and extrapallial fluids

Mobilization of hemocytes toward the extrapallial fluid has been described in juvenile Crassostrea virginica affected with another shell disease similar to BRD, Juvenile Oyster Disease (JOD), by Bricelj et al. (1992), who reported diapedesis of hemocytes through the mantle epithelium into the extrapallial fluid and onto the organic deposit. Similar observations were associated with the presence of bacterial bodies in the extrapallial space of juvenile $C$. virginica with extrapallial abscesses (Elston et al. 1999). In the case of Ruditapes philippinarum, infiltration of hemocytes has been histologically observed in the connective tissue of the 
mantle in clams affected with BRD by Santamaria et al. (1995). The mobilization of hemocytes to the CEF and PEF of diseased clams observed here and in previous work (Allam 1998, Allam et al. 2000) reinforces the hypothesis of a role of these cells in fighting the disease agent, which are found at high levels in this space, and in repairing the damage. The presence of hemocyte-like cells on periostracal lamina fragments, near the pathogen, supports our hypothesis. In vivo phagocytosis of Vibrio tapetis by hemocytes present in the CEF of $R$. philippinarum has already been described (Allam 1998).

A high percentage of dead cells (PDC) has been described in the extrapallial fluid of oysters affected with JOD (Paillard et al. 1996). In our study, the percentage was higher in diseased than healthy clams and it increased with the degree of infection (with high BRD Index). Similar results are already described in experimentally infected clams (Allam et al. 2000). However, reasons for this increase are not clear, especially in the HE. It may be due to the previously described hemolytic, cytotoxic and exotoxic activities of Vibrio tapetis (Borrego et al. 1996b) which was able to kill Ruditapes philippinarum hemocytes in vitro (Lane 1997, B.A. unpubl. data). Complex factors may also be involved: the poor physiological conditions of diseased clams after long periods of infection; other bacterial strains may be implicated since the total bacterial microflora increase significantly in diseased clams (Maes 1992, Allam et al. 1996). It is interesting to note that the PEF contained the highest PDC. This may be the result of direct interactions between hemocytes present in the PEF and $V$. tapetis abundantly present in this compartment, within the periostracal lamina and the organic deposit.

Low protein contents are observed in the $\mathrm{HE}$ and CEF of heavily diseased clams. This could be the result of the low metabolic activities already described in experimentally infected individuals with advanced stages of the disease (Plana \& Le Pennec 1991, Plana et al. 1996). In the oyster Crassostrea virginica, individuals infected with Haplosporidium nelsoni had low HE and tissue protein (Ford 1986, Barber et al. 1988) when compared to healthy oysters. Also, as suggested by Chu \& La Peyre (1993) in other circumstances, the decrease in HE protein may be the result of a defence strategy more favorable to cell (hemocyte) production to the detriment of circulating proteins.

In cell lysates, no significant differences were observed in mean lysozyme activity between healthy and diseased clams. This could be biased by the kinetics of synthesis and release of enzyme from hemocytes to plasma, a process already described in clams and oysters (Cheng et al. 1975, Cheng 1992, 1996). However, heavily diseased clams displayed the lowest lysozyme activity in their cell lysate of $\mathrm{HE}$ and CEF (Table 3). This may also be the result of an increase in the percentage of dead cells in seriously affected clams, resulting in a decrease in lysozyme activity per million cells since negative correlations were found between cell pellet lysozyme and the percentage of dead cells in CEF ( $\mathrm{r}=-0.43, \mathrm{p}=0.0018)$ and HE $(\mathrm{r}=-0.27$, $p=0.058$ ). Conversely, when compared to healthy individuals, diseased clams showed a depression in lysozyme activity in the supernatant of the HE but a significant increase for the CEF and PEF. This disparity underlines the specificity of this humoral response within the extrapallial fluids. Experimental challenge of Ruditapes philippinarum with Vibrio tapetis also induced an increase in lysozyme activity in the CEF supernatants (Allam et al. 2000). This enzyme is believed to play a role in defence processes in bivalves (Cheng 1983, Chu 1988). In addition to its direct lytic effect, lysozyme enhances the bactericidal effect of antibacterial proteins against Gram-negative bacteria even if these bacteria are not lysed by this enzyme (Smith et al. 1995). High lysozyme activity described here in extrapallial fluids of diseased clams undoubtedly plays a protective role against $V$. tapetis and/or possible secondary infections of the mantle.

An effective host defence reaction results in the neutralization of the pathogen and damage repair. The shell repair process (recalcification), usually associated with a decrease in Vibrio tapetis (and total bacterial microflora) burden in clams (Allam et al. 1996), was observed here in $82 \%$ of diseased clams. This process may be related to the efficiency of the defence response (e.g. high THC and lysozyme activity, other parameters, etc.) that leads to the neutralization of the pathogen by means of phagocytosis and direct killing. Indeed, the CEF of some diseased clams was bacteriologically sterile despite the presence of the characteristic organic deposit within the central compartment of the shell (Table 4, clam nos. 2 and 12). These results underline the efficiency of defence factors in the extrapallial fluids in neutralizing invading microorganisms. The clams were collected during the late spring, a period associated with phytoplanktonic bloom and food availability. Favorable nutritional conditions may help the clams in fighting the infection since laboratory experiments demonstrated a positive effect of food availability on the THC and the resistance of clams (weak development of BRD) (Plana \& Le Pennec 1991, Oubella et al. 1993).

In summary, we have demonstrated the presence of BRD in England. The etiologic agent, Vibrio tapetis, was isolated from diseased individuals. As in France, this disease may limit clam farming productivity in Great Britain. With regard to the defence response to the infection, the described increase of defence factors 
in 'peripheral compartments' (CEF and PEF) in clams affected with a bacterial shell disease suggests a role of these pseudo-internal compartments in the preservation of clam health. The results also indicate that future work on bivalve immunity and defence, particularly in the case of shell diseases, should consider further the role of these fluids.

Acknowledgements. B.A. was supported by a fellowship from the French Government. We thank Alain Marhic and Alain Le Mercier for technical assistance, and Michel Auffret for valuable discussions

\section{LITERATURE CITED}

Allam B (1998) The role of bivalve extrapallial fluids in immunological defense. The case of brown ring disease in the Manila clam, Ruditapes philippinarum. PhD thesis, Université de Bretagne Occidentale, Brest

Allam B, Auffret M (2000) The presence of an inducible antibacterial activity in the hemolymph of the Manila clam, Ruditapes philippinarum. Leb Sci J (in press)

Allam B, Paillard C (1998) Defense factors in clam extrapallial fluids. Dis Aquat Org 33:123-128

Allam B, Paillard C, Maes P (1996) Localisation of the pathogen, Vibrio P1, in clams affected with brown ring disease. Dis Aquat Org 27:149-155

Allam B, Paillard C, Auffret M (2000) Alterations in hemolymph and extrapallial fluid parameters in the Manila clam, Ruditapes philippinarum, challenged with its pathogen, Vibrio tapetis. $J$ Invertebr Pathol (in press)

Barber JB, Ford SE, Haskin HH (1988) Effects of the parasite MSX (Haplosporidium nelsoni) on oyster (Crassostrea virginica) energy metabolism. II. Tissue biochemical composition. Comp Biochem Physiol 91A:603-608

Bayne CJ (1983) Molluscan immunobiology. In: Saleuddin ASM, Wilbur KM (eds) The Mollusca, Vol 5, Physiology, Part 2. Academic Press, New York, p 407-486

Borrego JJ, Castro D, Luque A, Paillard C, Maes P, Garcia MT, Ventosa A (1996a) Vibrio tapetis sp. nov., the causative agent of the brown ring disease affecting cultured clams. Int J Syst Bacteriol 46:480-484

Borrego JJ, Luque A, Castro D, Santamaria JA, MartinezManzanares E (1996b) Virulence factors of Vibrio P1, the causative agent of brown ring disease in the Manila clam, Ruditapes philippinarum. Aquat Living Resour 9:125-136

Bradford MM (1976) A rapid and sensitive method for the quantitation of microgram quantities of protein utilizing the principle of protein-dye binding. Anal Biochem 72: $248-254$

Breber P (1985) L'introduzione e l'allevamento in Italia dell'arsella del Pacifico, Tapes semidecussatus Reeve (Bivalvia, Veneridae). Oebelia 11:675-680

Bricelj VM, Ford SE, Borrero FJ, Perkins FO, Rivara G, Hillman RE, Elston RA, Chang J (1992) Unexplained mortalities of hatchery-reared, juvenile oyster, Crassostrea virginica. J Shellfish Res 11:331-347

Cheng TC (1981) Bivalves. In: Ratcliffe NA, Rowley AF (eds) Invertebrate blood cells, Vol 1. Academic Press, London, p 231-300

Cheng TC (1983) The role of lysosomes in molluscan inflammation. Am Zool 23:129-144

Cheng TC (1992) Selective induction and release of hydrolases from Crassostrea virginica hemocytes by certain bacteria. J Invertebr Pathol 59:179-200

Cheng TC (1996) Hemocytes; forms and functions. In: Kennedy VS, Newell RIE, Eble AE (eds) The eastern oyster, Crassostrea virginica. Maryland Sea Grant, College Park, MD, p 299-333

Cheng TC, Rodrick GE, Foley DA, Koehler SA (1975) Release of lysozyme from hemolymph cells of Mercenaria mercenaria during phagocytosis. J Invertebr Pathol 25:261-265

Chu FLE (1988) Humoral defense factors in marine bivalves. Am Fish Soc Spec Publ 18:178-188

Chu FLE, La Peyre JF (1993) Perkinsus marinus susceptibility and defense-related activities in eastern oysters Crassostrea virginica: temperature effects. Dis Aquat Org 16:223-234

Dungan, CF, Elston RA (1988) Histopathological and ultrastructural characteristics of bacterial destruction of the hinge ligaments of cultured juvenile Pacific oysters, Crassostrea gigas. Aquaculture 72:1-14

Dungan CF, Elsion RA, Schiewe MH (1989) Evidence for colonization and destruction of hinge ligaments in cultured juvenile Pacific oysters (Crassostrea gigas) by Cytophagalike bacteria. Appl Environ Microbiol 55(5):1128-1135

Elston RA, Frelier P, Cheney D (1999) Extrapallial abscesses associated with chronic bacterial infections in the intensively cultured juvenile Pacific oyster Crassostrea virginica. Dis Aquat Org 37:115-120

Feng SY (1988) Cellular defense mechanisms of oysters and mussels. Am Fish Soc Spec Publ 18:153-168

Flassch JP, Leborgne Y (1992) Introduction in Europe, from 1972 to 1980 , of the Japanese manila clam (Tapes philippinarum) and effects on aquaculture production and natural settlement. ICES J Mar Sci 194:92-96

Ford SE (1986) Comparison of hemolymph proteins from resistant and susceptible oysters, Crassostrea virginica exposed to the parasite Haplosporidium nelsoni (MSX). J Invertebr Pathol 47:283-294

Ford SE, Kanaley SA, Littlewood DTJ (1993) Cellular responses of oysters infected with Haplosporidium nelsoni changes in circulating and tissue-infiltrating hemocytes. J Invertebr Pathol 61:49-57

Lane E (1997) Bacterial association with commercially important marine bivalves. PhD thesis, University of Glasgow

La Peyre JF, Chu FLE, Meyers JM (1995) Haemocytic and humoral activities of eastern and Pacific oysters following challenge by the protozoan Perkinsus marinus. Fish Shellfish Immunol 5:179-190

Maes P (1992) Pathologie bactérienne chez deux invertébrés marins. La maladie des lesions vertes des échinides réguliers et la maladie de l'anneau brun de la palourde Ruditapes philippinarum. PhD thesis, Université de Bretagne Occidentale, Brest

Mounkassa JB, Jourdane J (1990) Dynamics of the leukocytic response of Biomphalaria glabrata during the larval development of Schistosoma mansoni and Echinostoma liei. J Invertebr Pathol 55:306-311

Oubella R, Maes P, Paillard C, Auffret M (1993) Experimentally induced variation in hemocytes density for Ruditapes philippinarum and $R$. decussatus (Mollusca, Bivalvia). Dis Aquat Org 15:193-197

Oubella R, Paillard C, Maes P, Auffret M (1994) Changes in hemolymph parameters in the Manila clam Ruditapes philippinarum (Mollusca, Bivalvia) following bacterial challenge. J Invertebr Pathol 64:33-39

Oubella R, Maes P, Allam B, Paillard C, Auffret M (1996) Selective induction of hemocytic response in Ruditapes philippinarum (Bivalvia) by different species of Vibrio (Bacteria). Aquat Living Resour 9:137-143 
Paillard C, Maes P (1994) Brown ring disease in the Manila clam Ruditapes philippinarum: establishment of a classification system. Dis Aquat Org 19:137-146

Paillard C. Maes P (1995) The brown ring disease in the Manila clam, Ruditapes philippinarum. I. Ultrastructural alterations of the periostracal lamina. J Invertebr Pathol 65:91-100

Paillard C, Perclay L, Le Pennec M, Le Picard D (1989) Origine pathogène de l'anneau brun' chez Tapes philippinarum (mollusque, bivalve). CR Acad Sci Paris 309: $235-241$

Paillard C, Maes P, Oubella R (1994) Brown ring disease in clams. Annu Rev Fish Dis 4:1-22

Paillard C, Ashton-Alcox K, Ford SE (1996) Changes in bacterial densities and hemocyte parameters in eastern oyster, Crassostrea virginica, affected by juvenile oyster disease. Aquat Living Resour 9:145-158

Plana S, Le Pennec M (1991) Alterations de la glande digestive et conséquences nutritionnelles chez la palourde Ruditapes philippinarum contaminée par une bactérie du genre Vibrio. Aquat Living Resour 4:255-264

Editorial responsibility: Albert Sparks,

Seattle, Washington, USA
Plana S, Sinquin G, Maes P, Paillard C, Le Pennec M (1996) Variations in biochemical composition of juvenile Ruditapes philippinarum infected by a Vibrio sp. Dis Aquat Org 24:205-213

Roch P (1999) Defense mechanisms and disease prevention in farmed marine invertebrates. Aquaculture 172(1-2): $125-145$

Santamaria JA, Castro D. Luque A, Martinez-Manzanares E, Borrego JJ (1995) Histological alterations associated with brown ring disease. In: International workshop on shell disease in marine invertebrates: environment-host-pathogen interactions, March 29-31 Université de Bretagne Occidentale, Brest, p 35

Smith VJ, Findlay C, Schnapp D, Hutton DMC (1995) Detection of antibacterial activity in the tissues or body fluids of marine invertebrates. In: Stolen JS, Fletcher TC, Smith SA, Zelikoff JT, Kaattari SL, Anderson RS, Söderhall K, Weeks-Perkins BA (eds) Techniques in fish immunology, Vol 4. SOS Publications, Fair Haven, p 173-181

Sparks AK, Morado JF (1988) Inflamation and wound repair in bivalve molluscs. Am Fish Soc Spec Publ 18:139-152

Submitted: October 22, 1999; Accepted: February 21, 2000 Proofs received from author(s): May 23, 2000 